\title{
The Artist and the Art in ' $O$ Guarani', by José de Alencar, an adaptation by Pedro Pernambuco
}

\author{
Fabiana de Barros Monteiro Soares ${ }^{1}$ \\ Universidade Federal de Pernambuco, Brasil \\ Thelma Panerai Alves \\ Universidade Federal de Pernambuco, Brasil
}

\begin{abstract}
During the COVID-19 pandemic, The Familia Pernambuco'2, a folk-dance group, decides to gather people to produce an online video dance presentation and face the challenges of the year 2020 through art.

Formed by people of different ages and professional backgrounds, with artistic experience or not and spread around some cities in the world, the group was engaged in the process of the production of the show 'O Guarani' by Pedro Pernambuco, an adaptation of the homonymous work by the Brazilian romantic writer, José de Alencar.

The original work narrates the unconditional love of the indigenous, Peri for the young white lady, Ceci. For Pedro Pernambuco, Peri represents the artist who does everything to protect his love, the art, Ceci. Thus, this is the encounter of the Artist with the Art. In this adaptation all participants were invited to go deep in search of their own art and the meaning of it to their lives.

From this collection of home-made recordings, the group, formed only by volunteers, gathered everybody's participations to produce the narrative of their own findings as artists, who through the dance and the acting, defended the Art, as Peri did with Ceci.

Under the general direction of Pedro Pernambuco and Carmen Queiroz and with poems by Amélia Veloso ${ }^{3}$ and direction of choreography by José $W$. Júnior, the video dance show 'O Guarani', by Pedro Pernambuco will be released in the end of the first semester of 2021 on open video-streaming platforms.
\end{abstract}

Keywords: Collaborative process, Art in pandemic times, Home-made art, Brazilian folk-dance, Transmedia storytelling.

\section{Introduction}

The year of 2020 will be registered in the human History as a turning point. As it will be for the good or the bad, we still need time to figure it out. Nevertheless, it surely brought lots of reflections towards what really matters in life along with thousands of scientific papers regarding studies about the SARS-CoV-2 virus, treatments, vaccines and health and economy sequels throughout the world.

The Art in all its forms and expressions has always been considered a refuge, a safeguard to human most beautiful and dreadful feelings and thoughts. And since the pandemic has started it is easily observed how we rely on it to carry on our burdens. We have been consuming and producing art in the most various ways, having the technology working in our favour to enable homemade productions and broadcasts, from well-known artists to the newborn ones.

Immersed in this context, the project of 'O Guarani' was born. Let us call it as a project for now, because it turned out to be more than just an adaptation or a reread of the homonymous work of the reputed Brazilian romantic novelist of the $19^{\text {th }}$ century, José de Alencar. For this reason, it is important to detail the novel itself, the plot, and the historic context of when it was written as well as the project, its course, goals, and developments.

Moreover, this article will show the evolution of the process of turning the narrative of the original book into individual performances based on the adaptation of the original work. It turned out to be a transmedia storytelling (Jenkins 2006), as it went from the book to video, from written narrative to acting and dancing narratives.

Thus, this article is divided in four parts. First, we will get a picture of the original story and the context of the time when it was written. Second, we will learn how this project was born and the idea of the adaptation, who were the people involved, their productions and the upshots. Then, we will discuss how the outcomes accidentally showed that a transmedia storytelling can happen regardless the investments of the media industry or the existence of any blockbuster. And to conclude, we will bring the comments of the participants of the project, how they felt through the process and what benefits they derived from it while surviving the pandemic.

\section{1. 'O Guarani', by José de Alencar}

The novel 'O Guarani' was written in 1857 but is set on the first half of the 1600 s. It tells the story of $\mathrm{Ceci}$, the first protagonist. She is the daughter of a Portuguese nobleman who inherited an estate in the countryside of Rio de Janeiro as a retribution for the services rendered to the Portuguese Crown. She has a description of the perfect Romantic protagonist: blonde, blue-eyed, kind, and fragile.

The second protagonist is Peri, an indigenous who has conquered the friendship and respect of the nobleman's family for having saved Ceci from an avalanche of rocks. He is depicted as a strong and brave man, with an unsophisticated manner and a naive soul.

The story takes place at the estate of this nobleman, named D. Antônio Mariz, where there is a big house built in the models of medieval European castles, on the top of a mountain and on the banks of the River 
Paquequer. The property is organised according to the Portuguese colonial models, where vassals and slaves swear eternal loyalty to their lord. There were also knights, adventurers, noblemen and mercenaries in search of gold and silver who lived on the estate.

They were led by a former Italian priest named Ângelo di Lucca, who was disguised under the name of Loredano and who had a plot to destroy the family and kidnap their daughter, Ceci. However, all his attempts were frustrated by Peri, the hero of the story.

At certain point, D. Diogo Mariz, the nobleman's son and Ceci's brother, accidentally kills an indigenous woman from the tribe Aimorés. This event provokes attempts of revenge. The first is an attempt to kill Ceci while she is swimming in the river. Peri, always ready to protect his lady, manages to kill the two indigenous who tried to attack her.

As a result, the tension between the Aimorés and the family gets worse, and Peri decides to surrender in a heroic act of sacrifice. However, his is hindered by Álvaro, the nobleman's foreman. Back to the house the siege increases and D. Antônio Mariz understands that the final attack is eminent and requests Peri to save Ceci.

But to do so, he needs to be converted to Christianism, otherwise, the nobleman will not trust his daughter to her saviour. He accepts the conversion and leaves the house with her on a small canoe. Ceci is asleep due to the wine her father gave her.

The Aimorés invade the house. At this moment, D. Antônio Mariz explodes the powder bunker he had in the house. At the distance, Peri sees the house on fire. When Ceci wakes up, he tells her what happened, and she decides to live with in in the forest. It starts to rain heavily; the water starts to rise very quickly. Peri pulls a palm tree off the ground to improvise a new canoe. They climb up on it and the story ends with the image of the two of them disappearing on the horizon.

It is important to contextualize the time when this story takes place. It is considered one of the biggest representations of the Brazilian Romanticism, so it depicts what was considered the beauty of nature and human emotions and values of that time. It focuses on the exoticism and on the history as well as on spiritual and supernatural elements.

Regarding the main characters, Peri was considered uncapable of noble or gentlemanly gestures. Not being Christian, he did not have a soul. He was depicted as part of the Brazilian nature, like the forests and animals. Likewise, Ceci was delicate and pure. She could not defend herself, as well as make her own decisions.

These points are important to be considered when reading the next part of this article to understand the adaptations and interpretations made to the original work.

\section{2. 'O Guarani', an adaptation by Pedro Pernambuco}

The arrival of the SARS-CoV-2 virus in the end of 2019 provoked, along with fear and uncertainty, a search for ways to survive the pressure of the moment. The consumption and production of Art, in all its forms, became more than necessary to fulfil the routines and minds of millions of people around the world. And thanks to the Internet, concerts, plays, and performances could be broadcasted. Even when pocket shows or gigs happened in an empty street or on a balcony of an apartment, these moments were recorded and gained the world through social media platforms.

Around the month of May, 2020, with most of the people locked down in their homes, Pedro Pernambuco and Carmen Queiroz, the directors of the Familia Pernambuco, a Brazilian folk-dance group, decided to adapt the novel 'O Guarani' into a home-made dance performance. They invited some people to take part in the project and opened a free-enrolment period in their Instagram profile. Around 63 people enrolled for the project and a Whatsapp group was created for the kick-off.

The first task was to produce a short self-presentation video as most of the people were unknown among themselves. The group was formed by people of various age and professional backgrounds. Some had artistic experience, others had never tried dancing or acting and were letting themselves try it for the first time. As it was an online project, not everybody resided in Recife, the city of origin of the Familia Pernambuo. There were people from São Paulo, Belém do Pará, Olinda and even from Portugal (Lisbon and Alenquer). Then, according to the profiles of the components, Pedro and Carmen assigned some jobs to some participants. So, there would be a choreography director, a music director, a producer, a researcher, a costume designer, a film editor, among other important roles, and the cast.

The directors of the group instructed the participants to read the novel or watch its film version to get the gist of the plot. Almost every week there was a new exercise to be done regarding both the dance and the theatrical preparation. The type of dance chosen was the Caboclinhos, a folk dance inspired in the dances of the indigenous peoples of Brazil. So, every week, the teachers provided videos on the Familia Pernambuco YouTube channel with sets of steps. The steps were taught, and the cast was invited to record their repetitions and send to the teachers in the Whatsapp group. The teachers would give feedback to the participants.

Along with the dance repetitions, the group was invited to do some exercises which included body expression and reflections on themes that would be discussed in the video dance show. For instance, the cast was invited to get inspired by the painting of Edvard Munch, The Scream, to create their own expression of fear and pain to one of the first scenes.

There were also moments of reflections such as a lecture about the history and the situation of the indigenous peoples in Brazil, taking into consideration the indigenous' perspective of their history, as well as their resistance and culture. The lecture ${ }^{4}$ was given by an anthropologist professor Eliana de Barros Monteiro, who is specialist in indigenous theme. Then, 
the participants were also invited to reflect about the resistance of their bodies, and to try to find the artist inside themselves through exercises in front of a mirror. All these were thought to conduct the cast through the scenes of the show.

The scenario was each one's bedroom, balcony, garden, living room. There was no characterization with costumes of the original dance, but the clothes, lights and colours chosen were there to present the tension and emotion of each scene. The cast was free to adapt the location, only observing the elements determined by the directors for each scene, such as the colours of the clothes and some figurative elements to create some special effects, like torches, candles, cloths, mirrors, for instance.

The antagonism, represented by the battles against the Aimorés in the original story, was contextualised in this adaptation with everyone struggling to survive the pandemic. There were five scenes, besides the prologue. The scenes were linked by sequences of steps of Caboclinhos. This dance would guide the audience through the adaptation.

Therefore, we should now present the plot of the video dance, in the way Pedro Pernambuco conceived it. His main idea was to reframe the main characters, Ceci and Peri. Ceci became the Art in all its forms and beauty. The one who is desired and cherished. Sometimes pure and flawless, sometimes unreachable. Peri is the Artist. The one who wants to save the Art anyway, who will battle until the end to defend his beloved one. There were two components who played the roles of Peri and Ceci. However, the others in the cast had to seek for their own Art inside themselves and defend it as Peri did with Ceci. In the end, each one was searching for their own way to express themselves through this process where new artists were born during a time when the Art could be the safe haven or an escape hatch to overcome the obstacles imposed by the pandemic.

The prologue presents the spirits of the forest, represented by the whole cast. Everybody is wearing black, and the music comes together with the narration of the first poem of the story, all of them written by the poet, dancer, and director of the Maracatu Nação Pernambuco, Amélia Veloso. And to represent this moment it is said, in a free translation:

\footnotetext{
And this light that is born in me

That shines like this

And this light that lights me up

Transcends

On my face

It's from my body, the soul

It's the fire in my heart

It's from the gesture, the calm

It's the moment of emotion

Where everything starts

In this love that does not cease

It does not cease.
}

(Poem for the Prologue, Amélia Veloso, free translation)
Then, it comes the first sequence of dance with everyone dancing the Caboclinhos. The idea is that each sequence of dance will work as a page turner to indicate that the story will then continue. Everyone is wearing black with elements of fire and lights to adorn the set chosen.

The first scene starts with the poem translated below and refers to the encounter between Ceci and Peri. Ceci, the Art, is dancing on a beach in daylight, whereas Peri, the Artist, is dancing on the same beach at night. It follows the scene the cast at their homes representing their own encounter with the art. They are wearing red and looking through a mirror. Then, the cast dance the Caboclinhos opposite a mirror to celebrate the love of this moment.

\author{
And on that brief instant \\ Between the act of looking and the act of seeing \\ The enchantment occurs \\ In the tiny space \\ Between the feeling and the perception \\ The birth occurs \\ Between the body and the step \\ Between the sound and the beat \\ It vibrates in me, the art \\ And, besides the love \\ Passion occurs \\ (Poem for Ceci and Peri, Amélia Veloso, \\ free translation)
}

The second scene represents the Aimorés, their suffering, their fights for resistance. The idea was to represent all the people that are excluded or repressed due to their origin, skin colour, or any other kind of prejudice. The cast represents the indigenous people and is wearing green, brown and orange. The acting and the sequence of steps are representing the resistance of the indigenous people. And the third poem represents this moment:

\section{It hurts our body, our soul}

It hurts the blood

That, hot, toughens up the cold courage

The eyes bleed into tears of pain

And we shout out colourful words

There are so many colours

That, being insistent

Spill themselves over the world

We are all the colours

We do not want the pain

We are mosaics, multiple genes, and different

We are the difference imprinted in our faces, gender,

skin, hair

In the choices

We are choices

I, mine

You, yours

We are the truth

Home truth

Without a gesture to shut us up

Without a word to exclude us.

(Poem for the Aimorés, Amélia Veloso, free translation) 
The third scene is called Rebellion and represents the chaos. It is a battle against the ones who do not like the art. This moment also represents the conversion of Peri in his attempt to save Ceci. He becomes the Artist to save the Art. The scenery here represents the pandemic, and the cast is wearing black, red, and brown. Each one chose an object to represent his or her weapon to fight the war. For instance, some weapons were books, flowers, musical instruments, colourful ribbons, and folk props. The steps of Caboclinhos in this scene are danced in its fastest beat to show the strength and tension of the moment, as well as the words from this poem narrated in this scene:

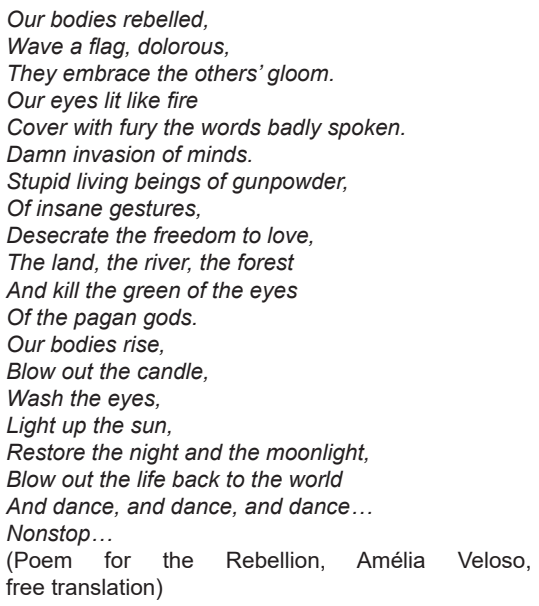

The fourth scene is the Revelation, when Peri tells Ceci about his conversion to save her. The newly born artists dance wearing white, blue, and purple and put into words what art means to them. The collection of testimonies proves that the artists won the battle, and the art is safe and sound with each of them. Veloso's poem reveals the benefits of having the art in our lives:

The dance, as in a photograph,

Reveals to us, slowly,

New ways to live,

To act, to move

The dance, as a wisdom

Opens our minds

And reveals the beauty of being

And the constant need of love

The dance is a conscious renounce

That moves storms away

To harvest calmness

The dance is a present

That knows how to grief the absence

And insist on smiling hope.

(Poem for the Revelation, Amélia Veloso, free translation)
The final scene is called Ecstasy and it represents the feeling of pleasure of these newly born artists who led the art be present in their lives. The idea of the directors was to provoke a catharsis, where the dancers would dance nonstop until they got into a kind of trance, releasing strong emotions. For Pedro Pernambuco, this special moment represents the truly encounter with the art of the dance. The colours of the clothes were white, blue, and silver and the cast danced in a light location. And to close the video dance performance, the last poem by Amélia Veloso:

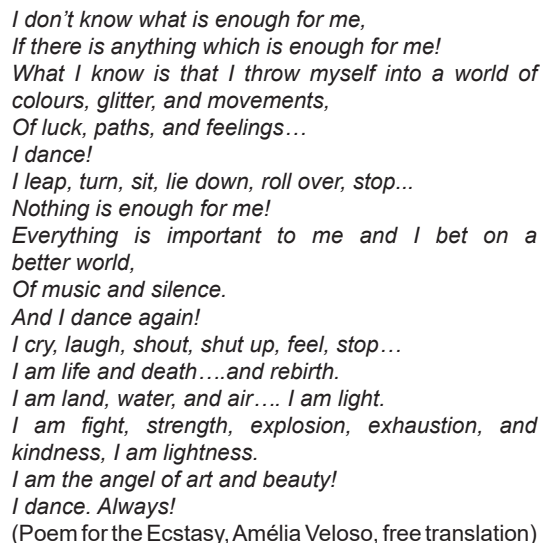

The end of the production phase represented a victory to the group. Every single scene produced by each component of the cast was totally homemade and recorded in smartphones. The direction of choreography was done by José $\mathrm{W}$. Júnior and he was also responsible for the theatrical preparation and acting. The whole group worked voluntarily and the edition of all the material collected during the process was under the responsibility of two experienced short film directors, Marcelo Sena and Felipe Marcena, who generously accepted the challenge of editing. In the end 35 people composed the cast, some of them had also some jobs in the production. Due to personal difficulties, 5 people left the group and other 23 preferred to remain in the group as a virtual audience. These people did not have the time to do the repetitions and record the scenes, but they gave feedback and support to the ones who were making their videos.

The next part of this article will discuss how this process turned out to be a transmedia storytelling, regardless the lack of investments or sophisticated use of state-of-the-art technology.

\section{3. 'O Guarani', a transmedia storytelling case}

Transmedia storytelling is a story that unfolds in different types of media with each new text adding influential contribution to the whole (Jenkins 2006). In Scolari, Bertetti and Freeman's words, "transmedia storytelling is a transversal phenomenon that covers 
any kind of narrative." $(2014,4)$. In a more explicit definition, Scolari (2013, 39, free translation) tells us that it is also:

a type of narrative where the story unfolds through different medias and communication platforms, and where part of the consumers assumes an active role of the process of its expansion.

These three extracts will contribute to explain why the adaptation of 'O Guarani', by Pedro Pernambuco, can count as a case of transmedia storytelling.

The original story is a book written in 1857. In 1870 the story was adapted to an opera, composed by Antônio Carlos Gomes and it was the first Brazilian opera acclaimed out of Brazil. It was first presented in Milan, Italy, in the Teatro alla Scala. Then it was turned into films. The first adaptation dates back of 1912, it was a silent film and is considered lost, as it has no registration of it today. In 1979 it was again produced by the filmmaker Fauzi Mansur, and the latest version is from 1996, produced by Norma Bengell. There was also an adaptation for a TV series in 1991. There were other printed editions such as, comics (i.e., in 1938), newspaper strips (1948), and as a cordel poem (2014), a popular literature practiced mainly in the northeast region of Brazil.

Scolari (2014) also points out that there are at least two types of expansions to be considered in transmedia storytelling: media and narrative expansions. As shown above and including the video dance performance into this discussion, we can notice that the story of ' $O$ Guarani' has achieved different medias. Regarding the narrative expansion, the adaptation presented in this article retells the story making a parallel with the Art, the Artist, and the pandemic. Not only on this adaptation, but we can also find expansions in at least two other examples: a short fiction tale called 'The Last of the Guaranys', written by Carlos Orsi Martinho and Octavio Aragão in 2012 for the American publisher Meteor House and the book series 'Wold Newton universe', created by the American Philip José Framer, where he connects popular characters, like Tarzan and Sherlock Holmes on his tales. In his universe, Tarzan travels through time and assumes the identity of Peri.

However, an important aspect of a transmedia storytelling is when the audience is the protagonist, making use of new forms of narratives. (Scolari 2013). This phenomenon also happened to 'O Guarani'. The adaptation made by Pedro Pernambuco meets the expansion on a video dance narrative when it presents an active and legitimised participation of all components, each one sharing his or her own view of the main characters, interpreting both Peri and Ceci, impersonating and discovering the Artist who inhabits his or her interior as well as defending and presenting the Art which is there to be consumed and to save their minds throughout the difficulties imposed by the pandemic.

All in all, looking at the whole project, even not intentionally - as it may happen to most of the transmedia storytelling examples, the video dance show turned out to be a space of personal and collective empowerment. From the book, set on the first half of the 1600 s and written by a Romantic novelist, to a video dance adapted by a folk-dance teacher and artist, with the inputs of all the components of the project, living a critical moment of the world's history, we can observe that a transmedia storytelling happened. Although without the support of any media industry for its production or disclosure, 'O Guarani', by Pedro Pernambuco proved the formula proposed by Scolari $(2014,4)$ when he says that "transmedia storytelling occurs when media and narrative expansions converge into a single narrative experience."

The next part of this article is devoted to show the thoughts shared by the group which transformed this adaptation into a unique narrative experience.

\section{4. 'O Guarani', the perception of the group}

This segment is dedicated to the comments and testimonies that were collected through the process of making 'O Guarani'. They can be simple, but not least emotional, as Gabriela Wanderley da Silva, a nursing student, put into words: "To be part of the 'O Guarani' was a moment of happiness in the middle of the pandemic." As for Rensch Reiva, ballet dancer and queen of the carnival for several times, the process was "a journey into one's intimate in the process of decolonizing him/herself with the body as an instrument", proving how profound the experience turned out to be.

Pedro Pernambuco, the creator of the adaptation, conducted the group through all the process. For him, who is an artist, to take part in the 'O Guarani' was a declaration of his love to the art. During his testimony he said that he would be nothing if there was no art in his life. He emotionally spoke that he cannot see himself doing anything else but art. He added that the pandemic showed him that the art is fundamental in the process of mental strengthening and for the general health of a person. He said that now he is even more connected to the mission that he chose for his life:

taking part in the 'O Guarani' was an opportunity to disseminate the love of the artist for the art, and the love of the art for the artist, through a video dance show, through art itself. We are chosen by the art as messengers of joy, love, life... and emotion. Participating in this is project was a lesson learned in life.

Maysa Rodrigues, a workpalce safety technician and a Bachelor of Dance said that the show 'O Guarani' let her connect to the art in an incredibly special way:

the art that rose in me in the middle of the pandemic, came with a good vibration of collective creativity. It fulfilled me and resulted not only on an artistic experience, but also on a gift for my soul. Besides all that, 'O Guarani' allowed us to reflect about the indigenous peoples, their resistance, and the richness of their culture. 
For Maria Thereza Caxias, a Psychology student, the experience was instigating, an awakening, it was a pleasure to be part of the project. It was in her words "a moment of affection, welcome, fun and artistic work in these dark and distressing times."

As for Catharina Leocádio, who is concluding her BA in Dance, '“O Guarani' was a rescue. It gave me the opportunity to connect to my ancestry, as my grandfather was an indigenous descendent."

For Marcelo Aguied, a ballet dancer and a folk-dance teacher dancing is liberating and transformative, and he felt like this during the project:

facing the pandemic, I was honoured to take part in this project which awoke in me the hope for better days. It was therapeutic. I am grateful for the Familia Pernambuco for helping me feel alive. The one who dances is happier.

Juliana Wanderley Lemos, a business administrator, highlights the innovative character of this project when she remembers the fact that it was all done remotely. "For me it was a unique experience. It was an opportunity to share art and dance in a virtual mode. It was amazing to feel the energy of everyone involved."

Mabel Carvalho, who has been working as an artist, especially dancing, for 30 years, highlights the spirit of solidarity and empathy that was the basis of the project, as the group worked to support the ones who needed any kind of help. She also reinforces the exercises of creating scenes also helped to deviate the attention of the surrounding problems that everyone was going through.

Ediane Ramos, a Physical Education teacher and dancer, agrees with Mabel Carvalho about the solidarity of the group and points out that it was a challenge the acting performances and that she feels grateful for the opportunity of personal growth.

As for Carmen Queiroz, who co-directed this production with Pedro Pernambuco, the project made her think out of the box, brought another sense to being an artist and helped her see herself as a being who dances. Besides being a dancer, a folk-dance teacher, and a director, she is also a psychologist, and the process of 'O Guarani' allowed her to help some people, while counselling and sharing some thoughts with the ones who asked for her help in matters related to anxiety and anguish.

In the long run we can agree with Carvalho, Alves, and Silva (2018, 164, free translation) when they defend the video performances as active and legitimised digital narratives. As they say:

we see that the online and digital universe has been integrating territories, diverse realities, and different cultures, when the Modernity had separated everything, in a compartmentalised manner.

The diverse realities and different life backgrounds were connected in this project aiming at a unique purpose of defending and promoting art while facing, collectively, the most difficult moment of our recent history.

\section{Final Comments}

It is relevant to reinforce that all participants were volunteers on this project. Nonetheless, the gains were enormous for every participant. The amount of material collected permitted the creation of other products, such as videos rehearsals with the repetitions of the steps of Caboclinhos, which were posted in the Instagram profile of Familia Pernambuco and whole folk-dance classes in their YouTube channel.

Regarding the material produced by the cast dancing, acting and testimonials, there is a plan to transform all that into a documentary.

And boosted by the outcomes of this project, the Família Pernambuco decided to conclude José de Alencar's indigenous trilogy. Iracema, his second indigenous novel will be adapted to a live dance performance on the theatre. The rehearsals have already started, and the project will be sponsored by the Culture Fund from the government of Pernambuco, Brazil. The third novel, Ubirajara, is planned to be adapted to a live street performance.

The video dance show 'O Guarani', by Pedro Pernambuco will be released in the end of the first semester of 2021 on open video-streaming platforms, with the general direction of Pedro Pernambuco and Carmen Queiroz, choreography direction of José W. Júnior, Music and Image direction of Marcelo Sena and Felipe Marcena.

\section{Final Notes}

${ }^{1}$ This study was financed in part by the Coordenação de Aperfeiçoamento de Pessoal de Nível Superior - Brasil (CAPES) - Finance Code 001.

${ }^{2}$ Família Pernambuco - YouTube Channel <https://www. youtube.com/channel/UCAIZA2rfA1XTSEpKMidlrsg>

Instagram - @familiapernambuco

${ }^{3}$ Amélia Veloso, poet and director of Maracatu Nação Pernambuco:

Instagram - @ameliavelosodemorais

${ }^{4}$ Lecture delivered by Prof. Eliana de Barros Monteiro, Ph.D.:

$<$ https://www.youtube.com/watch?v=loU2flCxzV8>

\section{References}

Alencar, José. 1857. O Guarani.

Carvalho, Ana Beatriz Gomes Alves, Thelma Panerai and Silva, Heitor da. 2018. "Drag queens nas redes: representatividade, visibilidade e ativismo digital na luta contra a violência simbólica." In: Identidades: novas configurações em territórios múltiplos. Organizador por Ribeiro, Joyce Otâmia Seixas Rodrigues, Eliana Teles e Halbmayer, Ernest. 157-174

Jenkins, Henry. 2006. Convergence Culture - where old and new media collide. New York University Press.

Scolari, Carlos Alberto. 2013. Narrativas Transmedia: cuando todos los medios cuentan. Deusto.

Scolari, Carlos Alberto Bertetti, Paolo and Freeman, Matthew. Transmedia Archaeology - storytelling in the borderlines of science fiction, comics, and pulp magazines. 2014. Palgrave Macmillan. 